IRENA ADAMEK

Uniwersytet Pedagogiczny im. KEN w Krakowie

\title{
Nauczyciel dziecka w kontekście zniewolenia i samostanowienia Podmiotowe i nie podmiotowe style pracy nauczyciela
}

Zniewolenie - ubezwłasnowolnienie, usidlenie, zatrzymanie, uzależnienie, zmuszanie zgnębienie, podporządkowanie.

Samostanowienie - autonomia, niezawisłość, samodzielność, samowystarczalność, niezależność

Wsparcie - zachęta, pomaganie, porada, doradztwo, konsultacje.

Model edukacji człowieka oświeconego odchodzi w przeszłość. Nadeszła era kształcenia innowacyjnego zorientowana transgresyjnie $\mathrm{z}$ dominacją nad orientacją zachowawczą. Rodzi się więc pytanie: Jacy nauczyciele radzić sobie będa najlepiej $w$ świecie otwartym, ale nieprzejrzystym i zmiennym? Na pewno gruntownie wykształceni, rozumiejący dylematy różnorodności kulturowej, tolerancyjni, ale krytyczni i odważni, umiejący elastycznie reagować na zmienność warunków pracy, otwarci na dialog. Ponadto z silnymi charakterami, ze stałymi zasadami, wspartymi na uznawanym systemie wartości. Ponadto tacy, którzy rozumieją ucznia w jego świecie wewnętrznym i zewnętrznym, w przyrodzie, kulturze i w społeczeństwie, wśród innych krajów i w procesie dziejowym $^{1}$, wykorzystując do tego najnowsze technologie informatyczne.

Co znaczy być dobrym nauczycielem? Można uczyć ciekawie, z polotem i pasją, można też $z$ natchnieniem. S. Bortnowski używa na to określenia „giętkość dydaktyki" - samodzielność w rozwiązywaniu w nowy sposób zagadnień praktycznych $\mathrm{w}$ toku pracy $\mathrm{z}$ wychowankami. Ważnym tu jest styl pracy nauczyciela. Z. Kwieciński zauważa, że proponowana przez rekonstrukcjonistów pedagogia nie koncentruje się ani na szcześliwości dziecka, ani na przekazie gotowych treści $i$ wzorców kulturowych; skupia się bowiem na rozwoju dziecka jako madrego i dobrego wspótuczestnika robienia świata

${ }^{1}$ Z. Kwieciński, Mimikra czy sternik? Dramat pedagogiki $w$ sytuacji przesilenia formacyjnego, [w:] Spory o edukację. Dylematy i kontrowersje we wspótczesnych pedagogiach, pod red. Z. Kwieciński, L. Witkowski, Warszawa 1994, 16. 
lepszym, sprawiedliwszym, bogatszym kulturowo i gospodarczo ${ }^{2}$. I to jest sens podmiotowego widzenia miejsca ucznia w edukacji.

Nie podmiotowym jest styl instrukcyjny, który zasadza się na kontroli zewnętrznej dziecięcej aktywności, silnie ustrukturyzowanej, gdzie centralnq powinnościq nauczyciela jest przekaz wiadomości, zasad i sposobów działania oraz norm ich oceny ${ }^{3}$.

Dziecko charakteryzuje szczególny krytycyzm i dociekliwość, skłonność do podejmowania problemów egzystencjalnych i stawiania pytań o otaczający świat - przejawy późniejsze, to zanikanie tych zjawisk w edukacji szkolnej.

$\mathrm{W}$ procesie edukacyjnym zmiany zachodzące w uczniu wymagają od nauczyciela organizowania takich warunków, aby one prowokowały go do wielostronnego i wielowymiarowego działania. Holistyczne ujęcie „obrazu” dziecka stwarza możliwość jego rozpoznawania i poznawania w różnych sytuacjach edukacyjnych. Wolność ucznia może zapewnić tylko wolny nauczyciel, zatem ważne są też prawa nauczyciela. Stan kompetencji intelektualnych i etycznych warunkuje emancypacje nauczyciela, która jest interpretowana jako proces uwalniania sie od nacisków i sformalizowanych ograniczeń dotyczacych treści i form pracy $^{5}$. W praktyce emancypacja ujawnia się w działaniach twórczych i innowacyjnych, mających swoje podstawy w krytycznym widzeniu świata. Nauczyciel jako krytyczny partner ucznia zmienia również siebie.

Te zmiany zachodzące w uczniu wymagają od nauczyciela organizowania takich warunków, aby prowokowały go do działania wielostronnego i wielowymiarowego. Stąd główne oczekiwania wobec nauczyciela wczesnej edukacji dziecka, to takie, aby był świadomym i krytycznym interpretatorem zarówno własnej aktywności zawodowej, jak i otaczającego świata, przy czym jego aktywność winna być ukierunkowana na rozwój osobistej kompetencji krytycznej. Współcześnie obserwujemy dość często funkcjonowanie zdezorientowanego nauczyciela o wypracowanej mentalności radarowej, ukierunkowanej na sygnaty ptynqce najczęściej z metodycznego centrum, naciskanego przez nieprzejrzysty co do celów i założeń system ${ }^{6}$.

\footnotetext{
${ }^{2}$ Tamże, s. 48.
}

${ }^{3} \mathrm{~J}$. Bałachowicz, Kategoria podmiotowości jako wyznacznik przemian stylu pracy wspótczesnego nauczyciela, [w:] Nauczyciel w systemie edukacyjnym. Teraźniejszość i przyszłość, Kraków 2009, s. 8-17; J. Bałachowicz, Style działań edukacyjnych nauczycieli klas poczatkowych. Między uprzedmiotowieniem a podmiotowościa, Warszawa 2009.

${ }^{4}$ Zob.: M. Szczepska-Pustkowska, Dziecięce filozofowanie (filozofowanie z dziećmi) jako zasada pracy z uczniem, „Kwartalnik Pedagogiczny” 2008, nr 1.

${ }^{5}$ M. Czerepaniak-Walczak, Między dostosowaniem a zmianq. Elementy emancypacyjnej teorii edukacji, Szczecin 1994, s. 78.

${ }^{6}$ M. Lewartowska-Zychowicz, Nauczyciel (wczesnej edukacji) w relacjach wolności i przymusu, [w:] Pedagogika wczesnoszkolna - dyskursy, problemy, rozwiazania, pod red. D. Klus-Stańska, M. Szczepska-Pustkowska, Warszawa 2009, s. 172. 
W świecie uporządkowanych hierarchii stałych wartości może nastąpić prawdziwe porozumienie między dzieckiem a osobą dorosłą jeśli wyznacznikiem tychże stanie się układ relacji osobowych i rozwijająca się wraz z nim sytuacja komunikacyjna.

Co wynika z tych związków dla bycia nauczycielem? Jest to:

- pozbycie się roszczeń uniwersalizujących własną słuszność;

- uznanie praw dziecka do posiadania sądu, systemów wartości, mówienia „własnym głosem”;

- pozostanie otwartym na siebie - zamiast dążyć do zmieniania, „naprawiania” kogoś należy przede wszystkim podejmować wysiłek wzajemnego rozumienia;

- rozumienie dialogu jako obopólnego informowania się o własnych racjach, przeświadczeniach, a różnice nie muszą być niwelowane.

Konieczne jest dziś widzenie roli nauczyciela w trzech perspektywach:

teraźniejszej - jak sobie radzi wykorzystując posiadaną wiedzę i kompetencje (zasoby) - posiadana wiedza może zarówno ułatwić ten proces, ale może być również czynnikiem hamującym proces poszukiwania nowych oryginalnych rozwiązań;

przeszłej - jak to się stało, że tak pracuje a nie inaczej, jaka drogę edukacji przeszedł, aby osiaggnąć takie wyżyny „niefrasobliowści” i „bylejakości”;

przyszłej - jaka będzie droga dalsza, pozostawionego samemu sobie nauczyciela i jakie należy podjąć działania, aby tę drogę znacząco odmienić z widzeniem skutecznego zarządzania klasą - prawidłowego planowania i projektowania edukacji, informacji zwrotnej o uzyskiwanych efektach. Jakie w niej jest miejsce na samokontrolę - chodzi o zmiany wewnętrzne w osobowości nauczyciela, zaś istotną rolę odgrywają tu stymulacja, wzmocnienie, wzorce. Doświadczenia jednostki stanowią odniesienie, do którego będzie się ona odwoływać w dalszym swoim życiu. Konfrontować będzie to, co ją spotka później z doświadczeniami wyniesionymi z poprzedniego okresu.

Rozwój jednostki zależy od jakości wsparcia osób dla niej ważnych na każdym etapie pracy zawodowej. Nie zawsze, jak podkreśla W. Dobrołowicz trudności przedmiotowe są najważniejsze. Ważniejsze jest częstokroć pokonanie przeszkód tkwiących w grupach społecznych ${ }^{7}$.

\section{Inhibitory nauczycielskiej autonomii}

Blokady intelektualne, to oczywista przyczyna większości nieprawidłowych działań, ale oprócz nich mogą występować i rozwijać się:

- blokady psychiczne (lęki, zahamowania emocjonalne, niecierpliwość, zbytni pośpiech, sprzeczne motywy);

${ }^{7}$ Zob. W. Dobrołowicz, Psychika i bariery, Warszawa 1993. 
- brak świadomości celów działania;

- antytwórcze przekonania na swój temat;

- przekonania społeczno-kulturowe;

- niewłaściwe warunki zewnętrzne, czyli brak odpowiedniej zachęty, stymulacji, ukierunkowania, możliwości ćwiczenia i sprawdzenia się (nauczyciele widzą jak innowacje przychodzą i odchodzą, szkoleni i ,wspomagani”" do granic wytrzymałości);

- brak nastawień badawczych stąd wynikająca aktywność stereotypowa, naśladowcza, algorytmiczna, nawykowa odtwórcza - czyli działania przeciwstawne działalności twórczej;

- niewłaściwa motywacja,

- zaniżona samoocena,

- niski poziom logicznej oceny i myślenia krytycznego.

Skutkiem tych blokad są niewykorzystane potencjalne możliwości nauczyciela, ale także w konsekwencji dziecka.

Bariery mogą wystąpić w procesie adaptacji nauczyciela, która może mieć charakter:

- aktywny - autonomiczność we wszystkich obszarach życia szkolnego naturalność, otwartość aktywność, gotowość podejmowania różnorodnych zadań, ciekawość poznawcza - właściwe interakcje z innymi nauczycielami;

- bierny - niepewność brak aktywności, brak poczucia bezpieczeństwa bariery psychiczne (indywidualne) powodują, że nauczyciel zachowuje się jak w przysłowiowych ,dorożkarskich okularach” - jest zdolny działać tylko stereotypowo (zagubieni nowicjusze, zagubieni weterani);

- zły - (adaptacja blokująca rozwój), przeżycia lękowe wskutek utraty kontroli, pasywność, napięcia, stresy związane z kierowaniem klasą, brakiem znajomości i wykorzystania zintegrowanych strategii wpływu na zachowanie uczniów w klasie ze strategiami efektywnego nauczania itp., brak wiedzy na temat sprawdzonych koncepcji działania ( nauczyciele nieudolni, niekompetentni).

Następne bariery to:

- Elementy otoczenia społeczno-kulturowego - wchodzenie w rolę nauczyciela to proces złożony i zróżnicowany - dotychczasowy bagaż doświadczeń, wiedzy wyniesionej ze studiów, przygotowanie tworzy swoisty „horyzont” dla bycia dobrym nauczycielem.

- Ważna jest również siła tradycji w działaniach nauczycieli, co można tłumaczyć również eksperckimi zalecenia (ekspert, to człowiek, który przestał myśleć, on wie - F.L Wright; ekspert to ktoś, kto wie coraz więcej o mniejszej liczbie spraw - N. Butler))

W pracy nauczyciela pojawia się kilka faz:

- Niezgodność między tym co umie, a tym co aktualnie przed nim stoi jako zadanie - to źródło negatywnych emocji mogących mieć związek z tym jak rozwiązuje zadania - szczególnie ważna w tym momencie pomoc osób z zewnątrz nakierowana na wsparcie emocjonalne i poznawcze. 
- Reakcja na niezgodność - następuje tu spojrzenie w przyszłość i rewizja własnych zasobów - pojawiają się reakcje obronne (wycofywanie się, zwiększanie dystansu, brak chęci rozwiązania problemów) - pozytywne jest ukierunkowanie działania na konstruktywne rozwiązanie problemów - wsparcie społeczne podtrzymujące wiarę $\mathrm{w}$ osobiste możliwości podjęcia trudu rozwiązania problemów.

- Nowe zorientowania (przeorganizowanie osobowości) - dostrzeganie możliwości, motywowanie siebie - Erikson optymistycznie uważa, że człowiek może rozwijać się całe życie

A oto kilka refleksji dotyczących pracy zawodowej.

\section{Nauczycielka stażystka}

Na poczatku bytam petna entuzjazmu. Kocham dzieci, ale to co zobaczytam $w$ klasie $w 1$. miesiqcu mojej pracy przerosto moje oczekiwania. $Z$ moich planów uczenia „, po nowemu nic nie wyszto” Rozkrzyczane dzieci, $28 \mathrm{w}$ klasie, brak jakichkolwiek środków, podgladanie innych nauczycieli unaoczniło mi, że nie jestem wtaściwie przygotowana do pracy $w$ takiej szkole, $w$ której nie da sie uczyć. Podam przykład jednych zajęć: przygotowywatam się pare godzin, udało mi się z tego niewiele zrealizować z powodu braku zainteresowania uczniów, braku dyscypliny (nie moge sobie z tym poradzić, bo nikt mnie tego nie uczyt $w$ sytuacjach szkolnych - wiem sporo, ale z teorii). Starsi stażem nauczyciele, radzenie sobie młodego nauczyciela z problemem dyscypliny $w$ klasie, uważaja $z a$ jeden $z$ podstawowych wyznaczników jakości jego pracy. Wiaże sie to $z$ wieloma emocjami o negatywnym charakterze. Po miesiacu już wiem, że najlepszymi środkami dla mnie sq dobrze wykorzystane podręczniki (mam niestety ciagłe poczucie, że uczęźle).

\section{Nauczycielka studiująca zaocznie}

Kocham to co robię. Ciagle czytam i staram się wybrać coś ciekawego do pracy $z$ dziećmi. Powiem tylko tyle, że tego co uczycie na uczelniach odbiega $w$ znacznym stopniu od tego czego potrzebuje $w$ mojej pracy. Uczone teksty, pisane zza biurka czesto niewiele maja wspólnego z rzeczywistościa szkolna. Proponowatabym wielu „madrym”, aby poszli na miesiac do pracy, to może ich widzenie jakości pracy nauczyciela $i$ wizja dobrej szkoty nabrałaby cech normalności.

\section{Nauczyciela z 3-letnim stażem pracy}

Studentka - jestem fantastycznie przygotowana do pracy $z$ dziećmi $w$ klasach I-III. Widziałam $w$ trakcie praktyk sporo świetnych pedagogów. Jak porównuje to z moimi doświadczeniami szkolnymi, to wspótczesna szkoła jest całkowicie inna. Prowadzone zajęcia $z$ wykorzystaniem różnorodnych technik $i$ metod uświadomiła mi jaki potencjat intelektualny prezentuja już mate dzieci. Mam 
tylko nadzieję, że moja wiedze i doświadczenie będę mogła w sposób optymalny wykorzystać.

Często w klasach szkolnych obserwuje się stosowanie zasady uśre dniania, stawiania na przeciętność. H. Kwiatkowska mówi o utrzymywaniu dystansu między nauczycielem a uczniem, co jest wynikiem zawłaszczania, w którym inność jest niszczona, natomiast w związku wywłaszczenia chodzi o ograniczenie hierarchicznego układu pozycji nauczyciela i ucznia oraz związku: nadrzędność-podrzędność ${ }^{8}$.

Chorobliwy brak czasu na analizę pracy, na refleksję, na czytanie i studiowanie, na przyjaźnienie się uczniów ze sobą i nauczycielami wynika z zagubienia wartości, z braku wiedzy o człowieku, którego się chce kształtować9

$\mathrm{W}$ epoce informacyjnego spadku zapotrzebowania na wiedze jednorodna, dobrze uporządkowaną wszelkie przykładowe konspekty, gotowe materiały metodyczne są, moim zdaniem, bardziej przykładem bezradności niż pomocy. Te wszystkie czynniki determinują działania edukacyjne nauczyciela.

Do tego pojawia się wiele negatywnych ocen pracy nauczyciela, które nie posiadają uzasadnienie w szkolnej rzeczywistości. Do tego procesu tworzenia bezpodstawnych wyobrażeń o szkole przyczyniają się media oraz środowiska decydentów prawnych, politycznych, urzędników a także teoretycy zajmujący się omawianą tematyką. Przykładem takiej pracy jest dla mnie książka M. Dudzikowej Mit o szkole jako miejscu „wszechstronnego rozwoju” ucznia. Eseje etnopedagogiczne, która przedstawia bezpodstawne wyobrażenie dotyczące współczesnej reformy oświatowej.

Krytyczny dystans, metodyczne watpienie to jest to, co powinno dominować w ocenie pracy nauczyciela. Odżegnuję się od totalnego krytykowania stanu edukacji w szkole, proponuję natomiast ważenie ocen, szukanie sposobów rozwiązań służących dobrze polskiej szkole. Szkoła nie nadąża za zmianami transformacyjnymi, nigdy i nigdzie społeczeństwa z tej instytucji nie były do końca zadowolone. Dodać należy, że „zapóźniona” rozwojowo szkoła nie zgłaszała zapotrzebowania na autonomicznego nauczyciela ${ }^{10}$.

W związku z tym należy postawić pytanie:

Jacy nauczyciele, jakie strategie i metody są postrzegane jako skuteczne a jakie nie dają pożądanych efektów?

Gdybyśmy byli w stanie odpowiedzieć na te pytania, to mielibyśmy obraz idealnego nauczyciela.

${ }^{8}$ H. Kwiatkowska, Tożsamość nauczycieli. Między anomiq a autonomia, Gdańsk 2005, s. 107.

${ }^{9}$ Zob.: B. Dymara, Terapeutyczne wartości dziatań pedagogicznych, [w:] Problemy edukacji wczesnoszkolnej, pod red. B. Dymara, Kraków 1996.

${ }^{10}$ W. Hörner, M. S. Szymański (red.), Nauczyciel i ksztatcenie nauczycieli. Zmiany i wyzwania, Warszawa 2005, s. 227. 


\section{Od wzorców ku autonomii/samostanowieniu}

Wielu nauczycieli czuje się bezpiecznie, gdy wykonuje czynności zawodowe przez kopiowanie, naśladowanie wzorów działania. Nie dociekając teoretycznych uzasadnień wykonywanych czynności praktycznych zbliżają własne działania do kopiowanego wzoru. Powielają te schematy działania, które nie powodują trudności wychowawczych, nie wymagają modyfikacji i osobistego wysiłku $^{11}$. Według H. Kwiatkowskiej jest to początkowa faza rozwoju zawodowego, stąd można sądzić, że spora grupa pedagogów, otumaniona nadpodażą materiałów edukacyjnych, „gotowców” nie przywiązuje wagi do osobistego rozwoju.

Nauczyciele hołdują bardziej zasadzie ujednoznaczniania niż różnicowania, bardziej respektują wymagania czasu przeszłego i teraźniejszego niż przyszłego; zbyt precyzyjnie zarządzają edukacją, zbyt wiele nacisku kładą na tzw. „poprawną" organizację edukacji w porównaniu z eliminowaniem lub nieuwzględnianiem indywidualności.

Co jest tego przyczyną? Nowa rzeczywistość powoduje u wielu nauczycieli syndrom bezradności, czego przejawem jest przemęczenie, opór, lęki, poczucie rezygnacji, czy wręcz kapitulacja wobec pojawiających się zadań.

Piętnując różne niedoskonałości działań edukacyjnych nauczycieli, za mało uwagi zwracamy na to, że musi on uwzględniać w swojej pracy zadania bardziej złożone niż kiedykolwiek w przeszłości ${ }^{12}$.

Jak podkreśla J. Rusiecki dominowanie $w$ pracy nauczycieli instrumentalizти i kompetencji techniczno-metodycznych oraz niewystarczajqce zainteresowanie teoriami i różnymi koncepcjami pedagogicznymi, świadczy też o orientacji ksztatcenia nauczycieli $w$ kierunku roli konformistycznej i adaptacyjnej, deterministycznej, uległej i przedmiotowej, a nie kreatywnej, podmiotowej, autonomicznej i nonkonformistycznej ${ }^{13}$. Sa to nauczyciele „konformiści” - zdaniem cytowanego autora. Ten konformizm, zdaniem innego pedagoga ${ }^{14}$, i postawy adaptacyjne następują bardzo szybko i tym samym identyfikacja z jasno określonymi zadaniami, które są im często narzucane i ustanowione bez ich udziału. Spostrzegają siebie wtedy jako osoby, którym zleca się realizację programów i wynikających z tego określonych zadań, wobec czego ograniczają swoją rolę do obowiązków wykonawców, zakładając, że miarą wartości ich pracy jest efektywność, z jaką wykonują powierzone zadania.

\footnotetext{
${ }^{11}$ H. Kwiatkowska, Tożsamość nauczycieli..., s. 227.

${ }^{12}$ O. Speck, Być nauczycielem, Gdańsk 2005, s. 14.

${ }^{13}$ J. Rusiecki, Nauczyciele okresu transformacji - próby diagnozy zawodu, Olsztyn 1997, s. 187.

${ }^{14}$ Zob.: R. Kwaśnica, Wprowadzenie do myślenia o wspomaganiu nauczyciela $w$ rozwoju, [w:] Z zagadnień pedeutologii i ksztatcenia nauczycieli, „Studia Pedagogiczne”, pod red. H. Kwiatkowska, T. Lewowicki, Warszawa, t. 61.
} 
W praktyce obserwuje się tendencję deprofesjonalizacji w sensie wzrastającej zależności w obszarze działania. Objawia się ona tym, że nauczycielowi odbiera się możliwość wielu samodzielnych decyzji dotyczących doboru treści i metod poprzez rozbudowywane, do granic możliwości realizacyjnych, programy. Ukuto nawet na to zjawisko termin teacher proof curriculum (program nauczania sprawdzający nauczyciela) ${ }^{15}$.

Sądzić należy, że droga odchodzenia od wzorców zacząć się musi na etapie kształcenia w uczelniach - z jednej strony poznanie zmienności świata, przygotowanie do myślenia kontekstowego, $\mathrm{z}$ drugiej strony nabycie nie tylko kompetencji merytoryczno-dydaktycznych, ale i kompetencji kluczowych. Bez tych ostatnich nie jest możliwe autonomiczne funkcjonowanie nauczyciela $\mathrm{w}$ zawodzie bowiem przemiany społeczne spowodowały zapotrzebowanie na nauczyciela, którego cechuje pewna elastyczność emocjonalna, wytrwałość w dążeniu do celu, umiejętność kooperacji z innymi, zdolność elastycznego dopasowania się do środowiska przy jednoczesnym zachowaniu własnej tożsamości i własnego zdania (posiadający cechy asertywności i empatii) ${ }^{16}$.

To podejście do kształcenia nauczycieli jest o tyle trudne, gdyż nie znamy:

- teorii, z którą wszyscy się zgadzają;

- żadnej metody, która jest jednakowo skuteczna w przygotowywaniu do zawodu;

- modelu kształcenia akceptowanego przez wszystkich;

- czynności uczenia się, której wyniki do końca dałoby się przewidzieć, a i zaobserwować - niekiedy jest to niemożliwe;

- żadnych wniosków badawczych, których nie można by podważyć.

Diagnozując spojrzenie na dzisiejszy stan przygotowania nauczycieli do zawodu - w imię bezgranicznie pojmowanego pluralizmu i demokracji odmawiamy prawa do uzasadnionego wartościowania wzorców, czy ideałów wychowawczych takich lub innych koncepcji pedagogicznych. Odnosi się wrażenie, iż ludzie odpowiedzialni za ten proces chcą zmiany roszczącej sobie prawo do dominacji. Dotychczasowe założenia i jakość rozwiązań ma uprawnione miejsce do analizy również pozytywnej. Uzasadnione i sprawdzone koncepcje pedagogiczne, dobrze służące kształceniu polskiego nauczyciela nie mogą być odsuwane w cień z powodu posiadania niemodnej orientacji. Stan

\footnotetext{
${ }^{15}$ W. Hörner, M. S. Szymański (red.), Nauczyciel i kształcenie..., s. 41.

${ }^{16}$ W „Newsweeku” z 2010 r. nr 3, T. Stawiszyński w artykule pt. Doktor Judym musi odejść przytacza opinię prof. Chwedczuka- filozofa na temat Czym jest madrość?, który mówi, że mądrość to nie tylko czysto intelektualna sprawność, zaś dobre wyniki w nauce nie są wyznacznikiem czegokolwiek. A. Einstein uchodził za półgłówka, i dwukrotnie repetował, T. Capote zakończył edukację na siódmej klasie, wielu aktorów grających Szekspira nie miało nawet matury a S. Jobs mózg firmy Apple studiował 1 semestr i z hukiem wyleciał z etykietką osoby mało zdolnej, leniwej i nie rokującej nadziei. To oni jednak współtworzą obraz dzisiejszej kultury a nie ci z ocenami z wyższej półki.
} 
krytycznego ujmowania wszystkiego co wiąże się z edukacją jest oczywiście czymś naturalnym, gdyż w ogóle kulturze społeczeństw przewijają się tendencje pesymizmu bądź optymizmu.

Konkluzja z tych rozważań sprowadza się do sformułowania zadania podstawowego w edukacji nauczycieli, którym jest kształcenia umiejętności myślenia kategoriami przyszłości; pobudzanie ciekawości świata, uczenie elastyczności intelektualnej, zaś w konsekwencji zdobywania nowej wiedzy i przystosowywania się do nowej rzeczywistości, w której funkcjonuje szkoła. W odniesieniu do czynnych nauczycieli zamiast na nich narzekać i załamywać ręce nad poziomem ich pracy należy im pomóc, próbując ich zmienić i budząc w nich refleksję. Świadomy nauczyciel jest bowiem zdolny do samooceny i samodoskonalenia poprzez analizę i systematyczne badania oraz studia nad własnym sposobem pracy ${ }^{17}$.

O problemach związanych z jakością pracy nauczyciela, z którymi boryka się wiele społeczeństw świadczy m.in. tytuł jednej z prac: Jak sobie radzić z nauczycielami, którzy sq źli, zmęczeni, bezradni lub po prostu stuknięci $i^{18}$.

\section{Nauczyciel myślący kategoriami przyszłości}

W globalnej dyskusji na temat kształcenia nauczycieli położono nacisk na bardzo dobre przygotowanie merytoryczne oraz wyposażenie $\mathrm{w}$ umiejętności pracy z uczniem. Jednak dobre przygotowanie akademickie nie gwarantuje już sukcesu w klasie. Jest niezbędne, ale nie tylko ono jest ważne. Należałoby więc uwzględnić w przygotowaniu do zawodu:

- zmieniające się potrzeby rynku na kadry;

- uczenie się reagowania na zmiany i spotkania z wyzwaniami cywilizacyjnymi;

- kształcenie umiejętności w zakresie wyzwalanie pasji u uczniów (artystycznych, krajoznawczych, sportowych etc);

- aksjologiczny fundament aktywności zawodowej.

To tylko niektóre z wielu zapotrzebowań odnoszących się do edukacji nauczycielskiej.

Profesjonalizacja to wyjście od misji, poprzez identyfikację, przekonania kompetencje, zachowania. Prezentuje to poniższe ujęcie ${ }^{19}$. Model ten ukazuje droge ,dorastania nauczyciela” w zawodzie.

${ }^{17}$ Zob. J. Jones, M. Jenkin, S. Lord, Jak wspierać rozwój zawodowy nauczyciela, Warszawa 2008; E. McEwan, Jak sobie radzić z nauczycielami którzy sq źli, zmęczeni, bezradni lub po prostu stuknięci, Warszawa 2008.

${ }^{18}$ E. McEwan, Jak sobie radzić z nauczycielami...

${ }^{19}$ Wykład Prof. PhDr. Vladimiry Spilkowej CSc. pt. Kurikulárni reforma a promény učitelského vzdélávani na konferencji poświęconej przemianom w edukacji w Bratysławie, 9 XII 2009. 


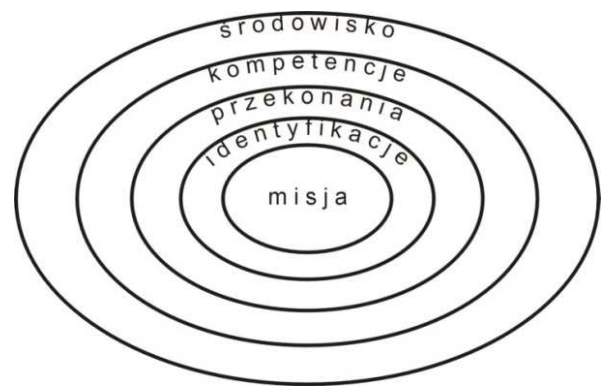

Przedmiotem profesjonalizacji jest wykształcenie refleksyjnego praktyka. A więc kierunki zmian, które wystąpić winny to:

- jakościowo inny rozwój nauczyciela i dziecka;

- akcent na indywidualność;

- wzmożony wymiar humanistyczny;

- akcent na działalność nauczycielską w obszarze - dialogu, tolerancji, konfliktu, oporu ucznia, braku akceptacji dla osoby nauczyciela.

Kształcenie nauczyciela, to także kształcenie człowieka wrażliwego moralnie i estetycznie; ma on występować w roli niekwestionowanego podmiotu nawiązanie do starej pedagogiki krytycznej i psychologii użytecznej dla poznania dziecka.

Jest to wszystko trudne, gdyż funkcjonowanie nauczyciela nie poddaje się formalizacji z powodu takich cech jak:

- niedookreśloność;

- niestandardowość;

- komunikacyjny charakter;

- dynamiczna zmienność zdarzeń.

Są to przesłanki do takiego kształcenia i dokształcania nauczycieli, aby mogli oni sprostać wymogom współczesnych czasów. Jest również powrót do przesłania o moralności, etyce i wyższych wartościach. Dobre przygotowanie akademickie nie gwarantuje już sukcesu w klasie. Stąd przygotowanie do pracy obejmować powinno dwie formy kształcenia: kształcenie przygotowujące do pracy zawodowej i ,praktykowania w klasie szkolnej oraz przygotowania do rozwoju zawodowego". H. Kwiatkowska podkreśla, że jest to miara wartości kształcenia wstępnego, rozwój bowiem jest wpisany w zawód.

Kwalifikacje nauczycielskie nie mają postaci finalnej. Praca w tym zawodzie nie jest działaniem technicznym i nie poddaje się w związku z tym formalizacji. Wszelkie próby precyzyjnego określania celów i środków ich osiągania nie wyczerpują struktury działań pedagogicznych, a styczność zachowań nauczyciela $\mathrm{z}$ zachowaniami ucznia rozstrzyga o elementarnym powodzeniu działań pedagogicznych.

Tej problematyce poświęca sporo uwagi Rada Europy, która w publikowanych raportach podkreśla potrzebę aktualizacji wiedzy nauczyciela ciagłość oraz umiejętności pozwalających dotrzymać kroku szybkiemu rozwojowi cywilizacji. 


\section{Kierunki zmian w edukacji nauczycieli}

Potrzebne są ogólne strategie działania pozwalające na przygotowanie nauczyciela postrzeganego jako ,transformatywnego intelektualistę" rzetelnie wykształconego, nastawionego na zmiany świata społecznego i życia jednostkowego. Ma to być „dobry” nauczyciel. Jak wpasowywać kształcenie nauczycieli w kontekst kulturowy i polityczny w różnych krajach? Wymaga to znalezienia odpowiedzi na pytania:

Co początkujący nauczyciel powinien wiedzieć i umieć robić (podstawa wstępnego kształcenia)?

Jak powinno wyglądać ciagłe jego doskonalenie? Jak ten proces powinien być wspierany przez system i decydentów?

Jakie role może odgrywać nauczyciel w ciagu swojej pracy zawodowej (szkoła, praca na różnych szczeblach administracji)?

Wyzwaniem jest więc dzisiaj przygotowanie nauczycieli ,po nowemu” oraz przeszkolenie istniejących zasobów.

Potrzebne są ogólne strategie działania pozwalające w toku kształcenia wykorzystywać wiedzę nauczycieli z zakresu teorii i metodyki wychowania, filozofii, psychologii etc.

Jak ważne jest to jak jest przygotowywany do pracy w takim wymiarze nauczyciel świadczy fakt iż Komisja Europejska powołała grupę ekspertów ds. podniesienia poziomu kształcenia nauczycieli. Zajęto się opracowaniem odpowiednich wskaźników do mierzenia poprawy jakości w dziedzinie kształcenia, a w szczególności ich ciagłego rozwoju zawodowego. Uznano, że jednym $\mathrm{z}$ priorytetów $\mathrm{w}$ działaniach na rzecz poprawy sytuacji jest rozwijanie systemów oceny $i$ akredytacji kształcenia i doskonalenia zawodowego ${ }^{20}$.

Przyłączenie się do globalnego dialogu jest możliwe, gdyż Polska może wnieść sporo do dyskusji ponieważ:

- reforma została zapoczątkowana w tym samym czasie, co w wielu innych krajach;

- ponieważ wszystkie kraje poszukują odpowiedzi, tak więc nowe rozwiązania w innych krajach mogą stać się przydatne w naszym kraju;

- możemy podzielić się z innymi krajami naszymi rozwiązaniami.

Nieodzownym więc wydaje się wprowadzanie nauczycieli w tajniki sztuki pedagogicznej, bardziej sztuki niż profesji. Oznacza to odejście od pedagogiki urabiania, pewności, dogmatyzmu w treściach kształcenia, czy też pompatycznej

${ }^{20}$ A. Nalaskowski, Monofonia - polifonia i anachronia programów szkolnych, [w:] Dylematy wczesnej edukacji, pod red. D. Klus-Stańska, M. Suświłło, Olsztyn 1998, s. 104. 
postawy w działaniu pedagogicznym); rozwijanie potrzeby samokształcenia i badania.

Podsumowując główne oczekiwania wobec nauczyciela w ogóle i także nauczyciela wczesnej edukacji to takie, aby był on świadomym i krytycznym interpretatorem zarówno własnych działań edukacyjnych jak i otaczającego go świata. Powinien go cechować podmiotowy styl pracy, wolny od zniewolenia spowodowanego realizacją narzuconych zadań, ustanowionych często bez jego udziału.

IRENA ADAMEK

\section{A child's teacher in context of enslavement and self-determination}

The author considers a contemporary image of the teachers and their model of education. She summarises it by formulating basic tasks such as: teaching the craft of thinking in the categories of the future, capturing the curiosity of the world, introducing an intellectual flexibility and as a consequence gaining new knowledge and adapting to the new reality in which the school operates. Only in that case the teacher will become a conscious and critical interpreter of both his own educational activities and the ones of the surrounding world, able to work in a subjective way, free of enslavement caused by the need of completing a given task, often appointed without his participation. 